
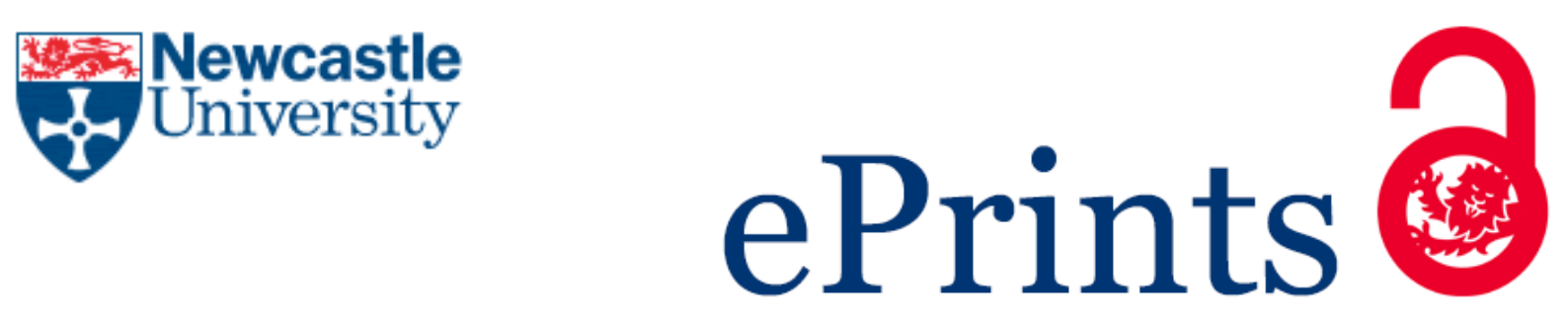

Membere E, Edwards S, Egwu U, Sallis P.

Bio-methane potential test (BMP) using inert gas sampling bags with

macroalgae feedstock.

Biomass and Bioenergy 2015, 83, 516-524.

Copyright:

(C) 2015. This manuscript version is made available under the CC-BY-NC-ND 4.0 license

DOI link to article:

http://dx.doi.org/10.1016/j.biombioe.2015.10.026

Date deposited:

$13 / 05 / 2016$

Embargo release date:

14 November 2016

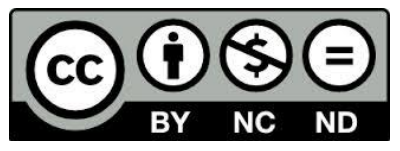

This work is licensed under a

Creative Commons Attribution-NonCommercial-NoDerivatives 4.0 International licence 


\section{Bio-methane Potential Test (BMP) using inert gas sampling}

2 bags with macroalgae feedstock.

3 Edward Membere : edward.membere@ncl.ac.uk, mimivicus@yahoo.com

4 Stephen Edwards, Uchenna Egwu, and Paul Sallis.

5 Newcastle University, UK

6 Abstract

$7 \quad$ An approach to Bio-methane potential test (BMP) was carried out at mesophilic temperature

8 of $35^{\circ} \mathrm{C}$ with Supe ${ }^{\mathrm{TM}}$ inert gas sampling bags as biogas collection and storage bags, using

9 selected seaweed (macroalgae) as substrate. Samples were given a range of pre-treatments 10 from washing, drying and macerating. Dried laminaria digitata (DD) with $68.14 \%$ VS (\%TS)

11 produced the highest BMP of $141 \pm 5.77 \mathrm{~L} \mathrm{CH} 4 / \mathrm{kg}$ VS, with methane content increasing to

12 about $70 \%$, while the lowest BMP of $93.35 \pm 5.03 \mathrm{~L} \mathrm{CH}_{4} / \mathrm{kg}$ VS with methane content of about

$1365 \%$ was obtained for fresh laminaria digitata (FD) with $72.03 \%$ VS (\%TS). Methane yields

14 of 97.66 and $67.24 \mathrm{~m}^{3} \mathrm{CH}_{4} / \mathrm{t}$ wet weight based on BMP results were obtained for $\mathrm{DD}$ and FD.

15 Both DD and FD achieved within $28 \%$ and $38 \%$ of the theoretical BMP value based on the

16 Buswell equation, respectively. The total methane $(V)$ produced was computed based on ;

$$
V=X_{1}+X_{2}-X_{3} \text { corrected to Standard temperature and pressure (STP) }
$$

where $X_{1}=$ daily calculated headspace methane volume, $X_{2}=$ daily measured volume of methane in gas bags, $X_{3}=$ previous day headspace methane volume. An advantage of this approach is the volumetric measurement of gas produced directly from the gas bags, hence it does not require liquid displacement or pressure transducers. Results from a second set of freshly collected sample seaweed sample showed it was in agreement with published BMP values. All analysis were carried out without mineral supplementation. 
 \\ 1. Introduction}

27 Anaerobic biodegradability $(A B)$ is a terminology now used to describe Bio-chemical

28 methane potential (BMP) [1-3]. It is defined as the fraction of compound(s) converted

29 to biogas (methane and carbon dioxide) under oxygen-free conditions mediated by a diverse mixture of microorganisms for an indefinite degradation time. But in practice the degradation time is definite and methane potential estimated from extrapolation of the experimented degradation curve [4]. AB can be determined by the volume of biogas produced, or the amount of substrate depleted or the formation of intermediates and end products [3]. The biochemical methane potential (BMP) test is the procedure developed to measure the volume of methane produced $[1,5]$. The assay was developed as a standardized method to determine the ultimate biodegradability [6] and associated methane yield during the anaerobic methanogenic fermentation of organic substrates [7]. It is a proven and reliable method to obtain the extent and rate of organic matter conversion to methane [8]. The parameter, ultimate methane potential $\left(\lambda_{\max }\right)$ from the BMP assay is regarded to a great extent as the determining factor for both design and economic details of a biogas plant [5]. The experimental BMP approach is simple; a characterized [9] and quantified organic substrate is mixed with a known anaerobic inoculum in a suitable medium (minerals and water) under defined operating conditions where the gas evolved is quantified by a specified measurement system until gas production virtually ceases [10]. Mixtures of nitrogen $\left(\mathrm{N}_{2}\right) 70-80 \%$ and carbon dioxide $\left(\mathrm{CO}_{2}\right)$ $20-30 \%$ are used as headspace gas to create anaerobic conditions, these prevent $\mathrm{pH}$ - change in the water phase due to $\mathrm{CO}_{2}$ from the headspace of the reactors [11], pure $\mathrm{N}_{2}$ alone has been also used [10]. Blank controls are included to account for the biogas produced from the inoculum alone, these are termed endogenous tests [1]. 
51 The blank control gives an idea of the volume of biogas produced by the substrate

52 alone [5]. Glass bottles with rubber septums as closed vessels are normally used

53 (Figure 1-1). The volume of the bottles range between $0.1 \mathrm{~L}-2 \mathrm{~L}[5]$ to $0.1-120 \mathrm{~L}$

54 [1], all depending on the homogeneity of the substrate used. It is recommended that

55 samples and blank assay should be carried out in triplicate for statistical significance

56 [5] because the BMP assay uses inoculum from different sources with varying quality

57 and these can be relatively heterogeneous [10, 11]. Furthermore, the biological

58 approach in determining methane potential leads to substantial uncertainty hence

59 triplicate samples should be used as a minimum [11].

60

\section{Figure 1-1: Bio-methane potential reactor and sampling illustration [11].}

Generally, the anaerobic biodegradability assay is used in triplicate [4] ; to establish biodegradability of substrate for products (biogas /intermediates) formation, determination of the ultimate biogas potential and rate of biodegradation. In the first category, most methods are based on monitoring biogas using gasometric techniques $[1,3-5,11]$ while different chemical analysis techniques are used to quantify formation of intermediates or substrate depletion [3]. In the gasometric methods, biogas is quantified either manometrically, by measuring pressure increase in constant volume or volumetrically as volume increase under constant pressure [1, $3,5]$, and also by gas chromatography $[1,2]$.

Volumetric methods comprise three approaches; displacement of a piston of a glass syringe inserted into the reactor, liquid displacement method using an alkaline solution for washing the biogas, or absorbing $\mathrm{CO}_{2}$ and collection of the biogas in a gas sampling bag with low permeability [1], e.g. aluminium foil bags [12]. During the manometric method, biogas produced in the reactors creates a proportional 
overpressure which are measured by pressure transducers of various kinds [3]. Both methods require a complementary gas analyser to obtain percentage composition of methane in the biogas.

Seaweeds are marine macro-algae which can be biologically degraded to methane [13].They can be utilized as a new promising biomass for the low-carbon economy,and recently have attracted attention as possible feedstocks for biorefinery ventures ([14]. Biorefineries are regarded as a sustainable technology that converts biomass into various marketable products, and energy [15]. Macroalgae have the potential of becoming a viable aquatic energy crop [16-18], but energy production from macroalgae is still limited due to economic viability [19].Figure 1-2 illustrates the current biofuel products from algae [19].

Figure 1-2: Current renewable fuel sources from algae [19]

\section{Materials and Methods}

\subsection{Collection, pretreatment and storage}

Algal biomass Laminaria digitata (LD) and Laminaria Hyperborea (LHY) used in the batch experiments were freshly collected from shallow water during low tide at Culler coats Bay, Tyne and Wear (NZ3572) on 19 ${ }^{\text {th }}$ December, 2013. The seaweed were transported in $1 \mathrm{~m}$ bags and were immediately washed to remove marine salts and sediments which can cause mechanical problems in digesters. Sand is known to be abrasive to moving parts such as mixers and pumps while salt removal leads to more stable digestion [20].

In preparation of the feedstocks, only the frond was used for $L D$, while stipe (stem) were used for the $L H Y$. Two categories of pre-treatment were carried out on both samples to obtain fresh slurry and a dried algal powder. For the slurry the 
99 fronds were roughly chopped by hand to particle size of about $10 \mathrm{~mm}$, while the stipe

100 was broken to smaller pieces $<5 \mathrm{~mm}$ using knives and hammer mill. Approximately

$101250 \mathrm{~g}$ of each were then macerated with $250 \mathrm{ml}$ of distilled water using a kitchen

102 blender to give consistent thick slurry (particles generally $<2 \mathrm{~mm}$ ) suitable for direct

103 addition to the reactors. The algal powder was obtained by oven dying the sample at

$104104^{\circ} \mathrm{C}$ for $24 \mathrm{hrs}$ and then pulverized with a Kenwood 100 coffee blender to particle

105 size generally $<1 \mathrm{~mm}$. Both types of pre-treated sample were labelled in 1 litre

106 containers and stored at $4^{\circ} \mathrm{C}$ until required.

\section{$107 \quad 2.2$ Inoculum}

108 The specific methanogenic activity test (SMA) is normally used to check the quality

109 of inoculum in anaerobic digesters. It is an indication of the efficiency of anaerobic

110 treatment process because it measures the rate of the methanogenic activity under

111 defined substrate conditions [21]. The SMA test is a quick and simple way to get

112 information about the percentage of active methanogenic microorganism in a sludge,

113 and also estimate the rate of maximum methane production of a reactor at a

114 particular sludge density [22], or capability [23] to convert volatile fatty acids into

115 methane under ideal conditions [23]. The test is performed with acetate, or acetic

116 acid, or mixture of acetic, propionic and butyric acids [24], because in non-

117 gastrointestinal environments like anaerobic digesters, acetate is one of the major

118 intermediates of fermentation [22] and is regarded as the principle precursor of about

$11970 \%$ of methane produced under typical operating conditions [25].The inoculum used

120 was collected from laboratory scale mesophilic anaerobic digesters running in the

121 environmental engineering laboratory, Newcastle University. It had been stored at

$1224^{\circ} \mathrm{C}$ for between $1-4$ weeks before use, and had the following characteristics; $\mathrm{pH}$

$1237.33,13.95 \%$ TS and 58.77\% VS (\%TS). The inoculum was pre-incubated using $2 \mathrm{~L}$ 
124 reactor bottles at $35^{\circ} \mathrm{C}$ for 3 days with waste beer COD concentration $117 \mathrm{~g} / \mathrm{L}$ to

125 restore / reactivate the methanogenic activity. Active biomass was confirmed by

126 good biogas production (1L biogas / $\mathrm{L}$ reactor / d) with $50-70 \%$ methane content in

127 the biogas (Figure 2-1).

129 Before using the pre-incubated inoculum for both SMA and BMP tests it was de-

130 gassed between 3-5 days until biogas production was negligible. The SMA test was

131 carried out by adding different amounts of sodium acetate $(\mathrm{NaAc})(1 \mathrm{~g} \mathrm{HAc}=1.37 \mathrm{~g}$

$132 \mathrm{NaAc})$ to $98 \mathrm{ml}$ of inoculum $(2 \mathrm{~g} \mathrm{VS} / \mathrm{L})$ in $0.5 \mathrm{~L}$ reactor bottles and the volume made

133 up to $400 \mathrm{ml}$ with de-ionised water. Then the procedure described for the BMP assay

134 [22] was used to carry out the SMA test. Acetate $(0.5-2.0 \mathrm{~g} / \mathrm{L})$ was used as

135 substrate since approximately $72 \%$ of methane formed during anaerobic digestion is 136 from acetic acid [26].

\subsection{Characterization of the sample}

$\mathrm{pH}$ was measured on the prepared substrate prior to digestion using a

139 Jenway $3010 \mathrm{pH}$ meter. The total solids (TS) and volatile solid [27] as \% TS, were

140 determined gravimetrically using methods described in [28]. VS was obtained by

141 placing the sample in triplicate into an oven for $24 \mathrm{hrs}$ at $104^{\circ} \mathrm{C}$, and these solids

142 subsequently placed in a furnace at $550^{\circ} \mathrm{C}$ for $1-2 \mathrm{hrs}$ to obtain the volatile solids

143 content.as a fraction of the total solid (\%TS) [28]. Total Kjeldahl Nitrogen (TKN) was

144 determined using Turbotherm acid digestion and Vapodest 30 S steam distillation

145 apparatus (C Gerhardt Lab Supplies,UK).10 ml of the samples were digested by the

146 Turbotherm in Kjeldahl tubes with $\mathrm{H}_{2} \mathrm{SO}_{4}$ and a $\mathrm{K}_{2} \mathrm{SO}_{4} / \mathrm{CuSO}_{4}$ Kjeltab tablet. The

147 digestate was then neutralised and steam distilled as described for ammonical 
148 nitrogen analysis [28]. The Total protein content was estimated by multiplying the

149 TKN value by $6.25[7,29]$. To obtain the percentages of carbon, hydrogen and

150 nitrogen for the generation of stoichiometric description of biomass, the fresh slurry

151 samples were firstly oven dried at $70^{\circ} \mathrm{C}$ for multiple 30 minutes periods until constant

152 weight obtained to remove moisture content, and passed through $1 \mathrm{~mm}$ sieve before

$153 \mathrm{CHN}$ analysis. Each pre-treated substrate stock was sampled and tested in triplicate

154 for total carbon $(\mathrm{C})$, hydrogen $(\mathrm{H})$ and nitrogen $(\mathrm{N})$ on a total solid basis. The

155 ultimate analysis for the fresh samples was carried out by Micro elemental Ltd,UK

156 using a CE Instruments (now Thermo) elemental analyser model EA1110 for CHN

157 and a Fisons instrument (now Thermo) elemental analyser model NA2000 for

158 oxygen and sulphur. The Instruments were calibrated and verified using certified

159 reference chemical, acetanilide $141 \mathrm{~d}$ traceable to NIST primary standards (ASTM

160 2005). A confirmation analysis was done for $\mathrm{CHN}$ using (Carlo Erba 1108 Elemental

161 Analyser,confidence limit $<0.3 \%$ ) by the Chemistry Department in Newcastle

162 University Upon Tyne.

1632.4 Assessment of Bio-methane potential energy from the Buswell 164 equation.

165 When the atomic or organic fraction composition of a compound is known, it is 166 possible to calculate the theoretical bio-methane potential $\left(B M P_{\text {theo }}\right)$ [4]. From the 167 experimental elemental analysis determination, the empirical formulae $\left(\mathrm{C}_{a} \mathrm{H}_{b} \mathrm{O}_{c} \mathrm{~N}_{d} \mathrm{~S}_{e}\right)$

168 can be calculated [10]. A stoichiometric equation can be developed using the

169 Buswell equation (Equation 1) [20] to obtain the $B M P_{\text {theo }}$ and Carbon Dioxide $\left(C_{2}\right)$

170 volumes produced when a substrate is broken down by a consortium of micro-

171 organisms present in a digester. 


$$
C_{n} H_{a} O_{b}+\left(n-\frac{a}{4}-\frac{b}{2}\right) H_{2} O \rightarrow\left(\frac{n}{2}+\frac{a}{8}-\frac{b}{4}\right) C H_{4}+\left(\frac{n}{2}-\frac{a}{8}+\frac{b}{4}\right) C O_{2}
$$

172 Assuming a total stoichiometric conversion of the organic compounds to methane 173 and carbon dioxide the methane yield $\left(B M P_{\text {theo }}\right)$ from the Buswell equation can be

174 calculated from Equation 2 ; [10].

$$
B M P_{\text {theo }} \text { yield }=\frac{\left(\frac{n}{2}+\frac{a}{8}-\frac{b}{4}\right) 22.4}{12 n+a+16 b} \quad\left(\text { STP } \frac{l C h_{4}}{g-V S}\right)
$$

\subsection{Modified Bio-methane potential assessment of pre-treated} 176 Substrate.

177 The modifield assessment was carried out in a water bath at mesophilic temperature of $35^{\circ} \mathrm{C}$. The batch reactors consisted of $500 \mathrm{ml}$ Duran bottles (actual internal volume $580 \mathrm{ml}$ ) fitted with rubber stoppers (Fisher brand Height 30 mm, bottom 29 $\mathrm{mm}$ ) with a $4 \mathrm{~mm}$ diameter stainless steel tube (45 $\mathrm{mm}$ long) inserted to serve as an outlet port for biogas collection in gas bags and as a purging port for Nitrogen

182 flushing of the headspace. The plastic bottle caps were used to hold the stoppers in 183 place (Figure 2-2) preventing any frictional movement of the stoppers as a result of biogas pressure build-up in the reactors and preventing loss and oxygen penetration into the reactors. A flexible PVC (non- oxygen / methane permeable) tubing connector $0.5 \mathrm{~cm}$ long was attached to the stainless, and a tube clip was used to

187 close the tube (Figure 2-2). Before starting the BMP test all reactor bottles were pressure tested for air leakage, and once the experiment has commenced, nitrogen or methane leakage using a thermo-scientific GLD ProLeak detector used to check any $\mathrm{CO}_{2}, \mathrm{NO}_{2}$ and $\mathrm{CH}_{4}$ leaks. The required amount of inoculum and substrate was evaluated for each reactor on a VS basis using a ratio of 3:1 (6 g VS / L : $2 \mathrm{~g}$ VS / L).

192 This was to ensure adequate destruction of the volatile solids and overcome possible 
193 VFA inhibition [5, 24]. The inoculum and substrate was then placed inside the reactor

194 and the solution was made up to $400 \mathrm{ml}$ with of de-ionised water. The rubber

195 stoppers were then used to closed the bottles, and the headspace (approx. $160 \mathrm{ml}$ )

196 was flushed for 5 minutes with pure (99.99\%) N2 gas to establish anaerobic

197 conditions. The tube clamp was used to close the PVC tube ensuring all the bottles

198 were gas-tight without the gas bags. Triplicates samples were used to overcome

199 inoculum variability, sample heterogeneity and allow statistical significance $[5,11]$

200 Figure 2-2: Modifield BMP reactor and gas collection bag

201 Biogas collection

202 Biogas collection started after $24 \mathrm{hrs}$ of digestion. Any biogas production was initially

203 contained within the headspace of the closed reactor and caused a causes a

204 proportional pressure increase within the reactors. Supel ${ }^{\mathrm{TM}}$ inert gas sampling bags

205 were attached to the PVC tubing connectors daily for collection of biogas. This was

206 achieved by releasing the clamps allowing the biogas to flow into the bags after

207 which they are reclamped before removal, ensuring no air penetration into the

208 reactor bottles. The collected biogas was allowed to equilibrate at room temperature

$20922 \pm 3^{\circ} \mathrm{C}$ before compositional analysis and volume determination. The gas bags

210 contained septa from which the gas was collected by gas syringe for analysis. It is

211 assumed that composition of the gas bag is proportional to the headspace of the

212 reactors.

213 Biogas and methane measurement

214 The methane composition in the biogas was determined using a GC-FID instrument

215 (Carlo-Erba $5160 \mathrm{GC}$ ) in split mode with the injector at $150^{\circ} \mathrm{C}$ and FID at $300^{\circ} \mathrm{C}$. 
216 Hydrogen was used as carrier gas at a flow rate through the column of $1 \mathrm{ml} / \mathrm{min}$.

217 Using a $100 \mu \mathrm{l}$ sample Lock syringe (Hamilton,USA), duplicate headspace samples

218 (100 ul) were taken from the sample bags and injected manually into the GC with the

219 inlet in a split mode (flow rate $100 \mathrm{mls} / \mathrm{min}$ giving a split ratio of $100: 1$ ). After the

220 initial injection the GC temperature programme and data acquisition commenced.

221 Separation was performed on a HP-PLOT-Q capillary column ( $30 \mathrm{~m} \times 0.32 \mathrm{~mm}$ i.d)

222 packed with 20 um Q phase. The GC was held isothermally at $35^{\circ} \mathrm{C}$ for $90 \mathrm{~min}$ and

223 heated to $250^{\circ} \mathrm{C}$ at $10^{\circ} \mathrm{C} / \mathrm{min}$ and held at final temperature for 10 minutes. Methane

224 standards were prepared prior to each analysis from $100 \%$ analytical grade $\mathrm{CH}_{4}$

225 (BOC Gases, UK) by injecting duplicate samples to make a five -point standard

226 curve in the range $20-100 \% \mathrm{CH}_{4}$. The volume of biogas produced was measured at

227 room temperature $22 \pm 3^{\circ} \mathrm{C}$ using a $100 \mathrm{ml} \mathrm{BD}$ Plastipak syringe to remove all

228 biogas from the gas bags. The methane composition (\%) calculated was multiplied

229 by the measured biogas volume giving the volume of methane produced at room

230 temperature. Measurement was carried out daily for the first 10 days, as between

$23180-90 \%$ of methane production is normally achieved within 8-10 days [11], thereafter

232 it was sufficient to measure twice week. Total volume of methane $(V)$ produced daily

233 was calculated by using Equation 3 and corrected to STP with Equation [4] [30];

$$
V=X_{1}+X_{2}-X_{3}
$$

234 where; $X_{1}=$ daily calculated headspace methane volume,$X_{2}=$ daily measured

235 volume of methane in gas bags, $X_{3}=$ previous day headspace methane volume.

$$
V_{d}=V \cdot \frac{\left(p-p_{w}\right) \cdot T_{O}}{p_{o}-T}
$$


236 Where $V_{d}=$ volume of dry gas in normal state, in $\mathrm{mL}_{\mathrm{N}} ; V=$ volume of gas as read

237 off, in $\mathrm{ml} ; p=$ pressure of gas at time of reading, in $\mathrm{hPa} ; p_{w}=$ vapour pressure of

238 water as a function of temperature of the ambient space, in $\mathrm{hPa} ; T_{0}=$ normal

239 temperature, $273 \mathrm{~K} ; p_{o}=$ normal pressure, $1013 \mathrm{hPa} ; \mathrm{T}=$ temperature of the gas or

240 ambient ,K

241

242

243

244

245

$$
B=B_{O} \cdot[1-\exp (-k \cdot t)]
$$

where $\mathrm{B}\left(\mathrm{mL} \mathrm{CH}_{4} \mathrm{gVS}^{-1}\right)$ is the cumulative methane yield, $\mathrm{B}_{o}\left(m L \mathrm{CH}_{4} g V S^{-1}\right)$ is the ultimate methane yield, $k\left(\right.$ day $\left.^{-1}\right)$ is the first order rate constant and $t(d)$ is the time.

The equation is a linear regression model based on the empirical relationship, and is used to determine the rate and extent of degradation, where the value of $k$ (slope of the linear plot ) shows the characteristics for a given substrate, and gives the time required to generate a ratio of the ultimate methane potential [5]. It should be noted because the kinetic model cannot be used to explain data obtained as the experimental data does not fit the proposed model Equation 4 [10]. 


\subsection{Second Set of Seaweed Samples}

260 In order to check and validate the proposed batch method, a second set of seaweed 261 samples were collected during low tide at Seaton Sluice, Whitley Bay (NE26) on 29 262 August 2014. Samples were subjected to the same pre-treatment described in 263 Section 2.1. The prepared feedstocks were : Fresh Laminaria Hyperborea Frond 264 (FHL), Fresh Laminaria Hyperborea Stipe (FHS), Dried Laminaria Hyperborea Frond (DHL), 265 Dried Laminaria Hyperborea Stipe (DHS) and Fresh Laminaria Digitata Frond (FDL), Fresh 266 Laminaria Digitata Stipe (FDS), Dried Laminaria Digitata Fond (DDL), Dried Laminaria 267 Digitata Stipe (DDS). Table 2-1 shows the characteristics of the samples.

268 Table 2-1: Charateristics of macroalgal samples

\section{Results and discussion}

\subsection{Inoculum}

The SMA was carried out at four different acetate concentrations $(0.5 \mathrm{~g}, 1.0 \mathrm{~g}$,

$2721.5 \mathrm{~g}$ and $2.0 \mathrm{~g} / \mathrm{L}$ ) each combined with $2 \mathrm{~g} \mathrm{VS} \mathrm{/} \mathrm{L} \mathrm{of} \mathrm{inoculum} \mathrm{to} \mathrm{ensure} \mathrm{substrate}$ 273 limitation did not occur [32]. Figure 3-1 show that the higher acetate concentrations $274(1.0,1.5,2.0)$ gave higher cumulative methane production rates. The daily methane 275 production ranged between $13.73 \mathrm{~mL} \mathrm{CH}_{4} \mathrm{~g} \mathrm{HAc}^{-1} \mathrm{~d}^{-1}$ on day 2 to $81.11 \mathrm{~mL} \mathrm{CH}_{4} \mathrm{~g}$ $276 \mathrm{HAc}^{-1} \mathrm{~d}^{-1}$ on day 8 (data not shown), while the lowest acetate concentration of $0.5 \mathrm{~g}$ 277 produced between $5.36 \mathrm{~mL} \mathrm{CH}_{4} \mathrm{~g} \mathrm{HAc}^{-1} \mathrm{~d}^{-1}-27.05 \mathrm{~mL} \mathrm{CH}_{4} \mathrm{~g} \mathrm{HAc}^{-1} \mathrm{~d}^{-1}$ on day 8 . 278 These values show a low methanogenic yield of the inoculum compared to typical 279 values of $350 \mathrm{~mL} \mathrm{CH}_{4} \mathrm{gVS}^{-1} \mathrm{~d}^{-1}$ obtained for granular sludge with acetate as 280 substrate [24] and $1000 \mathrm{~mL} \mathrm{CH}_{4} \mathrm{gVS}^{-1} \mathrm{~d}^{-1}$ for acetoclastic methanogens [32]. The 281 final methane composition was around $70 \%$ for all acetate concentration obtained, 282 except $0.5 \mathrm{~g}(50 \%$ methane).

283 Figure $3-1:$ a) plot of cumulative methane at different HAC concentration b) methane 
composition obtained at different concentrations HAC concentration.

\subsection{Characterisation of macroalgal substrates}

286 The physiochemical properties of the samples and inoculum were measured in terms

287 of $\mathrm{pH}, \mathrm{TS}, \mathrm{VS}, \mathrm{TKN}$ and elemental analysis as shown in Table 3-1.

Table 3-1: Elemental and physical analysis of macroalgal samples

289

290 Results showed that VS constitute a major part of the macroalgal biomass, ranging 291 from $63.19 \%$ in $D H Y$ to $72.03 \%$ of TS in $F D$. pH was in the range of $7.0-7.18$ in all

292 the reactor bottles before commencing digestion, which is ideal for methanogenic 293 bacteria [4]. Table 3-2 outlines the stoichiometric equation of the pre-treated algal samples while the analysis in Table 3-3 shows that fresh laminaria digitata (FD) with

$5.6 \%$ VS should give the maximum theoretical yield of $335.36 \mathrm{~L} \mathrm{CH}_{4} / \mathrm{kg}$ VS. Using this methodology, the theoretical maximum methane composition (\% methane in biogas) and the maximum biogas attainable from each sample is shown in Table 3-4.

Table 3-2: Elemental components for generation of the stoichiometric equation for macrogal 299 samples.

300 Table 3-3: Theoretical prediction of biogas production from macroalgal samples using the 301 Buswell Equation [20]

302 Table 3-4: Theoretical methane yields for pre-treated macroalgal samples

\section{$3033.3 \mathrm{CH}_{4}$ production}

304 Bio-methane production potential was measured under controlled conditions $\left(35^{\circ} \mathrm{C}\right)$

305 for 32 days. The cumulative and daily methane production profile are shown in

306 Figure 3-2 and Figure 3-3, respectively. Contribution from background $\mathrm{CH}_{4}$ produced 307 by the inoculum was deducted from the cumulative yield in evaluating the data. The appearance of the graph (Figure 3-1) conforms with the typical assay [5].

309 Samples of Laminaria Digitata and Hyperborea were subjected to a range of pre-

310 treatments from washing, drying and macerating. 
313 Cumulative $\mathrm{CH}_{4}$ yield obtained was the highest for washed and dried laminaria

314 digitata, with a value of $150 \pm 5.77 \mathrm{~L} \mathrm{CH}_{4} / \mathrm{kg} \mathrm{VS}$, with methane content increasing to 315 about $70 \%$ (Figure 3-3), while fresh laminaria digitata gave the lowest cumulative 316 yield of $100 \pm 5.03 \mathrm{LCH}_{4} / \mathrm{kg} \mathrm{VS}$, attaining $65 \%$ methane content. Chynoweth, Turick 317 [8] have documented values up $280 \mathrm{LCH}_{4} / \mathrm{kg}$ VS for the brown seaweed laminaria, 318 and between $126-174 \mathrm{LCH}_{4} / \mathrm{kg}$ VS for the fresh green seaweed Ulva [20]. Analysis 319 of Figure 3-1 indicates that there is no linearity of methane production rate over the 320 time period of maximum biogas production. Figure 3-2 shows that methane 321 production increased within the first $72 \mathrm{hrs}$, followed by a decline in production to a 322 basal level, then a transient recovery on day 26 based on this BMP method (after 10 323 days of biogas accumulation in the reactor headspace before measurement).

324 Biogas production started with an almost negligible lag time in all experimental 325 bottles, which confirms good microbial activity of the inoculum (as a result of pre326 incubation), and rapid digestibility of some macroalgal components as a result cell 327 wall disruption from the pre-treatment. Macroalgal cells have a tough and protective 328 cell wall which makes them highly resistant to bacterial attack [33], producing low 329 methane yields during fermentation process. Pre-treatment process can aid the decomposition the cells and improve methane production [34]

Figure 3-3: Macroalgal methane composition for pre-treated samples $F D, F H Y, D D$ and $D H Y$. 
334 (Table 3-5). This suggests that basic pre-treatments can improve hydrolysis rates $335[18]$ and enhance biogas production and yield $[16,20]$. The values are comparable to 336 (0.23 / d) obtained for dried Ulva, $(0.433 / d)$ food waste and $(0.239 / d)$ for grass 337 silage [20]. The $\mathrm{R}^{2}$ values (Figure 3-4) indicate a good fit of the first order rate model, $338 \log (\operatorname{In})((\mathrm{B} \circ-\mathrm{B}) / \mathrm{B} \circ)$ against time.

339 Figure 3-4: First order plot of the cumulative methane production of macroalgal samples $340 F D, F H Y, D D$ and $D H Y$.

341 Of all the substrates, FD had the lowest C:N ratio at 8.61:1 (Table 3-1) while

342 the other substrates were in the range 15:1 - 30:1 which has been proposed as

343 being optimum for anaerobic digestion [35]. Although there was no apparent

344 inhibition of methane production when the C:N ratio was less than $20: 1$, it is 345 assumed that the imbalance between carbon and nitrogen requirements of the 346 anaerobic microflora [36] could eventually lead to elevated ammonia levels in the 347 bioreactors, leading to failure [37, 38]. Ammonia toxicity is due to the accumulation of 348 total ammonia nitrogen (TAN), but specifically it is mainly from free ammonia $\left(\mathrm{NH}_{3}\right)$ 349 which inhibits methanogens, leading to the accumulation of volatile fatty acids 350 (VFAs) [39]. The selection of an appropriate inoculum to substrate ratio is one way of 351 overcoming VFA toxicity, allowing continued biogas production as the sludge 352 (inoculum) acclimatises to the substrate content or any inhibitory substances present 353 [40]. The inoculum to substrate ratio of 3:1 used in this research has been 354 recommended by various authors [5, 24], and as a result, inhibition from known 355 inhibitory compounds such as sulphide and phlorotannins, which are well described components of brown algae (phaeophytes) [41], did not occur in these batch tests. 
Table 3-5 compares the BMP results with the theoretical methane potential estimated from Equation 1. The fresh (FD) and dried (DD) samples achieved $28 \%$ and $36 \%$ of their theoretical values respectively. Allen [20] reported between $36 \%$ to $42 \%$ of the theoretical value achieved for pre-treated Ulva samples. The estimated methane yield was $103.56 \mathrm{~m}^{3} \mathrm{CH}_{4}$ / t wet for DD and $72 \mathrm{~m}^{3} \mathrm{CH}_{4}$ / $\mathrm{t}$ for FD, confirming that dried samples generated a higher volumes of methane than the fresh samples.

Table 3-5: BMP results compared to theoretical yield.

\subsection{Methane Production (Second Seaweed Samples)}

365 The BMP results (cumulative methane production) is shown in Figure 3-5. The 366 appearance of the graph for all samples agrees with typical example proposed by 367 Angelidaki [5]. Interestingly, both FDL (160.55 $\pm 1.44 \mathrm{~L} \mathrm{CH}_{4} / \mathrm{kg}$ VS) and FDS 368 (160.94 $\pm 2.68 \mathrm{~L} \mathrm{CH}_{4} / \mathrm{kg}$ VS) achieved the highest BMP followed by DDL (150.03 \pm $3690.78 \mathrm{~L} \mathrm{CH}_{4} / \mathrm{kg}$ VS), while FHL (107.49 $\pm 3.16 \mathrm{~L} \mathrm{CH}_{4} / \mathrm{kg}$ VS) showed the lowest 370 BMP after 38 days incubation at $35^{\circ} \mathrm{C}$. The values obtained for FDL differ 371 significantly from the first BMP results (Figure 3-1) supporting the fact that both 372 seasonal and compositional variation of macroalgae can affect BMP values [42]

Figure 3-5: Cumulative BMP for macroalgae samples (Second sample of seaweed)

Comparing the steeper curve between Figure 3-1 and Figure 3-5, the degradation rate $(k)$ was slightly lower for second seaweed samples with values ranging from $0.22-0.34$ (Figure $3-7$ ). The maximum percentage of methane obtained in all reactors was above $60 \%$ (Figure 3-6).

373 Figure 3-6: Percentage of Methane in biogas from BMP test as figure 3-5.

374 Figure 3-7: First order plot of cumulative methane production as figure 3-5. 


\section{4. Conclusion}

$376 \quad$ Marine seaweed are detrimental to the amenity of coastal bay often causing

377 eutrophication in water bodies. It has been reported that the approximate quantity of

378 energy in algae is about 6 calorie / $\mathrm{g}$ of which only about $40 \%$ is released from

379 mesophilic methane fermentation studies while the remaining $60 \%$ in the algae

380 biomass is resistant to release through decomposition partly because many cells and

381 walls remain intact through the fermentation process [34].Macroalgae pretreatment

382 before fermentation is used to overcome this limitation

383 A proposed modified new BMP method using Supel ${ }^{\mathrm{TM}}$ inert gas sampling bags

384 as biogas collection and storage system on all reactors were studied with

385 macroalgea as substrate. Pretreatment processes of washing, macerating and

386 drying were under taken to assess the algae strain with higher bio-methane

387 potential. Washed and dried laminaria digitata produced the highest BMP of 141.45

$388 \pm 5.77 \mathrm{~L} \mathrm{CH}_{4} / \mathrm{kg}$ VS with $\mathrm{k}\left(0.36 \mathrm{~d}^{-1}\right)$ and methane content of about $70 \%$ during the

389 period of experimentation. It can be concluded that both pre-treatment of the algae

390 and pre-incubation of the inoculum aided in the faster degradation rate observed in

391 all the substrate. The results shows that macro-algae has the potential to be a viable

392 source of generation of gaseous biofuel which are now known as third generation

393 biofuel [19] to differentiate first and second generation from terrestrial biomass which

394 have significant negative opinion to limit their production $[43,44]$. Results as shown

395 from the experiment two (Figure 3-5) proved the method is in agreement with a

396 typical BMP test appearance.[5]

397 The proposed modified BMP approach has certain inherent advantage over current 398 methods in use; 
399 I. Gas measurement converted to STP is carried out directly from the gas bags

400 at ambient conditions, so do not require liquid displacement or pressure

$401 \quad$ transducers.

402 II. Volume of methane produced is also directly measured from the gas bags.

403 III. Larger volume of reactor and substrate of heterogeneous nature can be $404 \quad$ added / used.

405 IV. Room for easy modification and adaptability to suite specific BMP process.

406 V. Easy application.

407 A disadvantage to this method could be the cost of the gas bags. It is highly

408 recommended that in applying this approach the duration of experimentation should

409 exceed the typical 30 day period for batch assay depending on substrate used as

410 evident in observed gas production after day 30 in this work. Hassan et.al. [11] has

411 proposed a 50 day period in their approach. Care should be taken not to have too

412 large a headspace in the reactor bottle leading to erroneous biogas and methane

413 estimation.

414 ACKNOWLEDGEMENTS

415 This work was supported by Tertiary Education trust fund (TEFUND), Nigeria. We

416 thank the Department of Civil and Geosciences, Newcastle University where the

417 study was undertaken. We are grateful to Paul Sallis, Gary Caldwell, and David race

418 for technical assistance during harvesting and analysis of the macroalgal.

\section{5. References}

420 1. Raposo, F., et al., Anaerobic digestion of solid organic substrates in batch 421 mode: An overview relating to methane yields and experimental procedures.

422 Renewable and Sustainable Energy Reviews, 2012. 16(1): p. 861-877. 
2. Rozzi, A. and E. Remigi, Methods of assessing microbial activity and inhibition under anaerobic conditions: a literature review. Re/Views in Environmental Science \& Bio/Technology, 2004. 3(2): p. 93-115.

3. Guwy, A.J., Equipment used for testing anaerobic biodegradability and activity. Reviews in Environmental Science and Biotechnology, 2004. 3(2): p. 131-139.

4. Angelidaki, I. and W. Sanders, Assessment of the anaerobic biodegradability of macropollutants. Re/Views in Environmental Science \& Bio/Technology, 2004. 3(2): p. 117-129.

5. Angelidaki, I., et al., Defining the biomethane potential (BMP) of solid organic wastes and energy crops: a proposed protocol for batch assays. Water science and technology ; journal of the International Association on Water Pollution Research, 2009. Vol.59(5): p. 927-34

6. Nizami, A.-S., N.E. Korres, and J.D. Murphy, Review of the Integrated Process for the Production of Grass Biomethane. Environmental Science \& Technology, 2009. 43(22): p. 8496-8508.

7. Raposo, F., et al., Assessment of process control parameters in the biochemical methane potential of sunflower oil cake. Biomass and Bioenergy, 2008. 32(12): p. 1235-1244.

8. Chynoweth, D.P., et al., Biochemical methane potential of biomass and waste feedstocks. Biomass and Bioenergy, 1993. 5(1): p. 95-111.

9. Bird, K., D. Chynoweth, and D. Jerger, Effects of marine algal proximate composition on methane yields. Journal of Applied Phycology, 1990. 2(3): p. 207-213.

11. Hansen, T.L., et al., Method for determination of methane potentials of solid

10. Raposo, F., et al., Biochemical methane potential (BMP) of solid organic substrates: evaluation of anaerobic biodegradability using data from an international interlaboratory study. Journal of Chemical Technology \& Biotechnology, 2011. 86(8): p. 1088-1098.

12. Parawira, W., et al., Anaerobic batch digestion of solid potato waste alone and in combination with sugar beet leaves. Renewable Energy, 2004. 29(11): $\mathrm{p}$. 1811-1823.

13. Park, J.-I., et al., Production of hydrogen from marine macro-algae biomass using anaerobic sewage sludge microflora. Biotechnology and Bioprocess Engineering, 2009. 14(3): p. 307-315.

14. Jung, K.A., et al., Potentials of macroalgae as feedstocks for biorefinery. Bioresource Technology, 2013. 135: p. 182-190. 
15. IEA. IEA Bioenergy Task 42 Biorefinery.2009; Available from: http://www.ieabioenergy.task42-biorefineries.com/.

16. Bruhn, A., et al., Bioenergy potential of < i> Ulva lactuca</i>: Biomass yield, methane production and combustion. Bioresource technology, 2011. 102(3): p. 2595-2604.

17. Chynoweth, D.P., J.M. Owens, and R. Legrand, Renewable methane from anaerobic digestion of biomass. Renewable Energy, 2001. 22(1-3): p. 1-8.

18. Costa, J.C., et al., Biomethanation potential of macroalgae Ulva spp. and Gracilaria spp. and in co-digestion with waste activated sludge. Bioresource Technology, 2012. 114: p. 320-326.

19. Jones, C.S. and S.P. Mayfield, Algae biofuels: versatility for the future of bioenergy. Current Opinion in Biotechnology, 2012. 23(3): p. 346-351.

20. Allen, E., et al., The potential of algae blooms to produce renewable gaseous fuel. Waste Management, 2013. 33(11): p. 2425-2433.

21. Dolfing, J. and W.G.B.M. Bloeman, Acitivity measurements as a tool to characterize the microbial composition of methanogenic environments. Journal of Microbiological Methods, 1985. 4(1): p. 1-12.

22. Valcke, D. and W. Verstraete, A practical method to estimate the acetoclastic methanogenic biomass in anaerobic sludges. Journal of the Water Pollution Control Federation, 1983. 55(9): p. 1191-1195.

23. Souto, T.F., et al., Influence of incubation conditions on the specific methanogenic activity test. Biodegradation, 2010. 21(3): p. 411-424.

24. Raposo, F., et al., Influence of inoculum to substrate ratio on the biochemical methane potential of maize in batch tests. Process Biochemistry, 2006. 41(6): p. $1444-1450$.

25. Kaspar, H.F. and K. Wuhrmann, Kinetic parameters and relative turnovers of some important catabolic reactions in digesting sludge. Applied and Environmental Microbiology, 1978. 36(1): p. 1-7.

26. McCarty, P.L., Anaerobic waste treatment fundamentals. Public works, 1964. 95(9): p. 107-112.

27. Laurinovica, L., et al. Biochemical methane potential of biologically and chemically pretreated sawdust and straw. 2013.

28. APHA, Standard Methods for the Examination of Water and Wastewater. 2005: American Public Health Association.

29. Allen, S.G., Chemical analysis of ecological materials. 1974: Oxford: Blackwell. 
501

502

503

504

505

506

507

508

509

510

511

512

513

514

515

516

517

518

519

520

521

522

523

524

525

526

527

528

529

530

531

532

533

534

535

30. VDI, VDI 4630 : Fermentation of organic materials -Characterisation of the substrate, sampling, collection of material data, fermentation tests. In: Verein Deutscher Ingenieure (VDI) (Ed.), VDI Handbuch Energietechnik. Berlin: Beuth Verlag GmbH:44-59. 2006.

31. Gunaseelan, V.N., Biochemical methane potential of fruits and vegetable solid waste feedstocks. Biomass and Bioenergy, 2004. 26(4): p. 389-399.

32. Ince, O., B.K. Ince, and O. Yenigun, Determination of potential methane production capacity of a granular sludge from a pilot-scale upflow anaerobic sludge blanket reactor using a specific methanogenic activity test. Journal of Chemical Technology and Biotechnology, 2001. 76(6): p. 573-578.

33. Mussgnug, J.H., et al., Microalgae as substrates for fermentative biogas production in a combined biorefinery concept. Journal of Biotechnology, 2010. 150(1): p. 51-56.

34. Chen, P.H. and W.J. Oswald, Thermochemical treatment for algal fermentation. Environment International, 1998. 24(8): p. 889-897.

35. $\mathrm{Xu}, \mathrm{F}$., et al., Comparison of different liquid anaerobic digestion effluents as inocula and nitrogen sources for solid-state batch anaerobic digestion of corn stover. Waste Management, 2013. 33(1): p. 26-32.

36. Speece, R.E., Anaerobic Biotechnology for Industrial Wastewaters 1996: Arche Press, Nashville, TN.

37. Chen, Y., J.J. Cheng, and K.S. Creamer, Inhibition of anaerobic digestion process: A review. Bioresource Technology, 2008. 99(10): p. 4044-4064.

38. Nielsen, H.B. and I. Angelidaki, Strategies for optimizing recovery of the biogas process following ammonia inhibition. Bioresource Technology, 2008. 99(17): p. 7995-8001.

39. Astals, S., V. Nolla-Ardèvol, and J. Mata-Alvarez, Thermophilic co-digestion of pig manure and crude glycerol: Process performance and digestate stability. Journal of Biotechnology, 2013. 166(3): p. 97-104.

40. Muruganandam, B., et al., Effect of Inoculum-Substrate Ratio on Acclimatization of Pharmaceutical Effluent in an Anaerobic Batch Reactor. Journal of Environmental, Science \& Engineering, 2008. 50(3): p. 191-196.

41. Connan, S., et al., Intra-thallus phlorotannin content and antioxidant activity in Phaeophyceae of temperate waters. Botanica Marina, 2006. 49(1): p. 39-46.

42. Adams, J.M.M., et al., Seasonal variation in Laminaria digitata and its impact on biochemical conversion routes to biofuels. Bioresource Technology, 2011. 102(21): p. 9976-9984.

43. Jung, K.-W., D.-H. Kim, and H.-S. Shin, Fermentative hydrogen production from Laminaria japonica and optimization of thermal pretreatment conditions. Bioresource Technology, 2011. 102(3): p. 2745-2750. 
536 44. Smyth, B.M., et al., Can we meet targets for biofuels and renewable energy in transport given the constraints imposed by policy in agriculture and energy? Journal of Cleaner Production, 2010. 18(16-17): p. 1671-1685.

539

540 